\title{
The Issue of Sovereignty: The Clarity Act as an Effective and Legitimate Response to Canada-Quebec Relations
}

MEGAN SETO

\section{Introduction}

Quebec sovereignty in the Canadian federation has elicited strong emotion across the spectrum of politics and national interest. The forwarding of the Clarity Act by Jean Chretien's Liberals was an attempt by the federal government to seek a resolution to the question of Quebec unilateral secession in a legal and clearly defined manner. The Act of 2000 was not of abstract materialization. Rather, it highlighted the complexity of Canada's multinational identity and the historical quandaries of her founding races. The Act was a response to the 1995 Quebec referendum, yet despite it being an attempt to provide clarity to concerns arising from the referendum, the Act has generated further debate and new anxieties regarding Canada-Quebec relations.

In the scope of this examination, the prelude to the Clarity Act involved two decades of discussions aimed at addressing "Quebec's place in Canada." The historical tensions between Canada-Quebec relations since 1980 - will be firstly examined; with emphasis on events defined as times of crisis or high intergovernmental relations. The second purpose of this study will regard an assessment of the derived 
origins of the Secession Reference and the Clarity Act. Finally, the central theme of this paper will be devoted to the divergent opinions of the Act both of its effectiveness and of its legitimacy. Thus, the third section of this study will place emphasis on the ramifications of the legislative Act. To prove this, the paper will define the meaning of "effective" and "legitimate" and apply this to the Clarity Act to determine its ability or inability to meet the desired meaning. As implied, the study of effectiveness will be centered on the federal government's goal orientation and debated success. The definition of legitimacy will be applied to the Clarity Act, where perception and legality will influence its ability to meet the defined standard. It will be demonstrated that the procured legislation of the Clarity Act did not sufficiently fulfill the gaps or intended goals of the federal government - in essence deeming it ineffective. The ineffectiveness of the Act is synonymously coupled with raised concerns of its legal authority, thus - weakening its lawmaking might, applicability and legitimacy.
Tensions within the Federation: Canada-Quebec Relations Since 1980 In 1980, Pierre Elliott Trudeau helmed the reins of political balance. His approach to Quebec had been of an aggressive battle to keep her within the fold of the federation. This nationalizing ethos was "aimed against the centrifugal forces of regionalism, province-building, and Quebec nationalism."1 This was potently displayed in the 1980 Quebec referendum. While a majority of Quebecers voted 60\%-40\% against the mandate to "negotiate sovereignty association" with Canada, the referendum served as a platform and catalyst for the repatriation of the Canadian constitution. ${ }^{2}$ The subsequent failure to include Quebec in the 1982 constitutional settlement

\footnotetext{
${ }^{1}$ Francois Rocher and Miriam Smith, "The four dimensions of Canadian federalism." in New trends in Canada federalism (second edition), (Peterborough : Broadview Press, 2003), 36. ${ }^{2}$ Robert Young, The Struggle for Quebec: From Referendum to Referendum? (Montreal \& Kingston: McGill-Queen's University Press, 1999), 8
} 
would generate two decades of

constitutional debate. Trudeau

defended the actions of his

government. He argued, "a 'separatist'

government of Quebec would never

have signed the Constitution Act."3

What is more telling of the

government though is the defense that

the Liberal federalist government was

more than willing to serve the interest of the Quebec people. ${ }^{4}$ This displays both a patronizing viewpoint of the central governments perspective of the province, but symbolically highlights the alienation of Quebec from the rest of Canada (ROC). It aided in the creation of the "us" versus "them" mentality within the federation, but the Trudeau defense also belittled and illegitimatized the sovereigntist leaders as incapable spokespersons of recognizing Quebec interests.

The Progressive Conservatives under Brian Mulroney faired similar benign success in bringing Quebec back into the constitutional agreement. The "honorable" Mulroney overtures towards Quebec were

${ }^{3}$ Rocher, Dimensions, 36.

${ }^{4}$ Ibid. perceived by the ROC as Quebec interests being "jammed down English Canada's throat." 5 This is evident in the failed agreements of the Meech Lake Accord and the latter attempt with the Charlottetown Accord. The demand for a "distinct society" clause by the Quebec premier, Robert Bourassa, was a pivotal factor in Meech Lake's failure. It perpetuated the fear of a hierarchy in rights. Though the Charlottetown constitutional package was reconfigured to include these concerns, the perception of asymmetry in Canada-Quebec relations created skepticisms amongst the ROC. During the inter-constitutional period, Quebec began to contemplate its legal authority to remove itself from the federation, as evident in the BelangerCampeau Commission and the Allaire Report. ${ }^{6}$ To defer a 1992 referendum,

\footnotetext{
${ }^{5}$ Alan C. Cairns, "Looking into the Abyss," in The referendum papers: essays on secession and national unity., ed. David R. Cameron (Toronto: University of Toronto Press, 1999), 201.

6 Peter Russel and Bruce Ryder, "Ratifying a postreferendum Agreement," in The referendum papers: essays on secession and national unity., ed. David R. Cameron
} 
the federal government reconfigured the initial "five demands" of Quebec in the new package. ${ }^{7}$ However, like its predecessor - Charlottetown failed.

Quebecers felt shut out. They argued that they were given a raw and reduced deal in comparison to Meech Lake, which Quebecers had supported. ${ }^{8}$ As evidence, they point to the removed Quebec distinct society clause, thus, furthering the gulf between Quebec and the federal government. Yet the rejection of the Charlottetown Accord by the ROC was perceived in Quebec as a rejection of even minimal demands for Quebec interests, leading to greater

(Toronto: University of Toronto Press, 1999), 325.

${ }^{7}$ The five conditions forwarded by Robert Bourassa were non-negotiable demands presented by the Quebec National Assembly to initiate constitutional negations with the federal government. They were: (1) Constitutional recognition of Quebec as a "distinct society" (2) Restoration of Quebec's veto on constitutional change. (3) Greater control over immigration (4) A role in selecting Supreme Court Justices and Senators from the province (5) Restrictions on the federal government's spending power in areas of provincial jurisdiction. Good, Kristen, 2008, Canada- Relations, 141 ${ }^{8}$ Cairns, Abyss, 235. disenchantment. The bitter memories of these failed accords served as catalysts for the 1995 referendum. The deferment lasted until 1995, where a new referendum asked for a "new economic and political partnership" between Quebec and Canada. ${ }^{9}$ The result was a hair thin victory for the "no" side of $51.6 \%$ to $49.4 \% .{ }^{10}$ Despite the endorsed agreement of the referendum question by the three Quebec powers; the Parti Quebecois, Bloc Quebecois and the $\mathrm{ADQ}$, the referendum question faced similar concerns as those expressed against the 1980 referendum: the question asked was not clear. ${ }^{11}$ There was a failure to state clearly that the voting was for non-reversal negotiations for Quebec independence. Confusion can be attributed to the vagueness of terms such as "association," and "sovereign;"

${ }^{9}$ Thomas Courchene, "The changing nature of Quebec-Canada relations: From the 1980 referendum to the summit of the Canadas," IRPP Working Paper Series, 08 (2004): 524-26.

${ }^{10}$ Ibid., 5 .

${ }^{11}$ Patrick Monahan, "Doing the rules: An assessment of the federal Clarity Act in light of the Quebec Secession Reference," C.D. Howe Institute (2000): 14 . 
providing ambiguous words that were not defined and contextually confusing for the voter. The close sovereigntist victory has also been attributed to Chretien's initial hands-off approach to the referendum. For scholars such as Patrick J. Monahan, the "yes" vote in 1980 and 1995 highlighted key constitutional gaps not addressed by the federal lobbyists, "a key element of the federalist strategy in the referendum campaigns of 1980 and 1995 was to emphasize the uncertainties associated with voting 'yes."'12 Ottawa's constitutional duty after a successful sovereignty campaign was uncertain, as there was no contingency plan. As David R.

Cameron acknowledges, "the narrowness of the federalists' win in the 1995 Quebec referendum demonstrated that we [ROC] can no longer afford to take an ostrich-like approach to the possibility of Quebec sovereignty." 13 Canadians began to think forwardly and placed sovereignty in a scope that dealt with

12 Ibid., 12.

${ }^{13}$ Russell and Ryder, Postreferendum, 326. it as valid possibility. Thus, the 1995 referendum legitimized the movement - the Supreme Court of Canada, legally would do the same.

\section{The Succession Reference and the} Clarity Act: the Constitutional

\section{Roadmap}

Under Allan Rock, the Liberal Justice Minister announced the intentions of the federal government to refer to the Supreme Court of Canada (SCC), three questions regarding Quebec's ability to unilaterally secede from Canada. As part of the Plan B initiative, the answer was intended to harden the government's position against Quebec by discrediting or weakening the sovereignty movement's legal authority. ${ }^{14}$ Known as the Succession Reference, the three questions asked were:

\footnotetext{
${ }^{14}$ Andree Lajoie, "The Clarity Act in its Context," in Quebec: State and Society (third edition), ed. Alain- G. Gagnon (Peterborough: Broadway Press, 2004), 35.
} 
(1) Under the Constitution of Canada, can the National Assembly, legislature or government of Quebec effect the secession of Quebec from Canada unilaterally?

(2) Does international law give the National Assembly, legislature or government of Quebec the right to effect the secession of Quebec from Canada unilaterally? In this regard, is there a right to self-determination under international law that would give the National Assembly, legislature or government of Quebec the right to effect the secession of Quebec from Canada unilaterally?

(3) In the event of a conflict between domestic and international law on the right of the National Assembly, legislature or government of Quebec to effect the secession of Quebec from Canada unilaterally, which would take precedence in Canada? 15

The SCC ruled in 1998 that in regards to the first question, Quebec could not

${ }^{15}$ Reference re. Secession of Quebec, [1998] 2 S.C.R. 217. unilaterally secede. On the second question, it ruled that the Quebec peoples could not be regarded as oppressed. It noted that the application for the international legal right to declare self-determination was not valid as it applied to colonial contexts. There was no conflict in law; therefore, the third question was not answered. ${ }^{16}$ According to Andre Lajoie:

The [Secession Reference], therefore, aimed not only to declare the unconstitutionality under Canadian law, but the invalidity, under international law, of any Quebec law that would propose a referendum...the Court chose to give Ottawa its "negative support," by indicating to the federal government how far both of them could go together." 17
16 Alain G. Gagonon, "Quebec's Consitutional Odyssey," in Canadian Politics., ed. James Bickerton and Alain-G. Gagnon (Peterborough: Broadview Press, 1999), 296.
17 Lajoie, Context, 153.


The fundamental aspect that would lay the foundation for the Clarity Act and qualify Lajoie's argument is with the SCC's ruling on a "clear question," a "clear majority," and the negotiations that were to take place if defined thresholds were met. The significance of the ruling is the SCC's decision to not define what constituted a clear majority and question. Instead they left the political question to politicians to quantify and define. The significance regarding negotiations was that the SCC ruled that if there was a sovereigntist mandate, which had been handed by the Quebec people based on a clear question and majority, the federal government had a constitutional obligation to negotiate with Quebec. They could not ignore it as Chretien had tried.

The applicability of the Secession Reference is fundamental to the Clarity Act, because the Reference served as a legal roadmap and intent for the legislative Act. The 1995 Act, led by Stephane Dion, was aimed to reconcile the recommendations of the SCC. The Act defined a clear question as one that includes a statement of
Quebec's intentions to form an independent state, void of ambiguity. The duty to negotiate could only be triggered if this requirement was met. ${ }^{18}$ Under the Act, the 1980 and 1995 referendum questions were deemed unclear.19 The second recommendation that the Clarity Act accepted was the attempt to define what constituted a clear majority. The Act defined this as "a clear expression of a will by a clear majority of the Canadian population of that province cease to be part of Canada." 20 It considers factors such as the size of the eligible and majority voters. It does recognize that the standard of $50 \%$ of valid voters +1 did not meet the standard that the Reference forwarded as a "substantial consensus." 21 The figure was not analogous with the decision making implications of provincial secession. Though both sides declared victory after the Secession Reference, the

${ }^{18}$ Monahan, Rules, 14. ${ }^{19}$ Claude Ryan, "Doing the Consequences of the Quebec Secession Reference: The Clarity Bill and beyond," C.D. Howe Institute (2000): 9.

20 Ibid., 31.

${ }^{21}$ Monahan, Rules, 13. 
application of its recommendations instead generated greater debate amongst politicians and scholars, where a divergence of opinion has been voiced. To study the implications of the Act, arguments relating to the Act's effectiveness and legitimacy will be forwarded in this paper.

The Effectiveness Of The Clarity Act: The Federalist Goals And The Sovereigntist's Response

To apply the term "effective," it will be defined as "producing a decided, decisive or desired effect."22 This piece of legislation failed to meet this definition of effectiveness. Its flaw is attributed to contradictions, failed objectives, and convolution - while achieving in areas such as minority rights and border issues. Does partial achievement sufficiently justify effectiveness? To conclude, we must examine the areas of dispute that the federal government attempts to clarify and challenge.

22Definition of Effective $<$ http://www.merriamwebster.com/dictionary/effective>, November 19, 2008
On the issue of a clear question, the intention was to provide clarity in the question making and voting process. Was the government effective in defining and conveying this intention? According to Monahan the ease of the question making process invoked in the Act involved a greater role of federal government intervention. Though the federal government cannot limit the question asked in a referendum, Monahan argues that the Act legitimizes the appropriateness of intervention by "submit[ting] the issue of the clarity of any referendum question to the House of Commons, permit[s] all parties to debate and formulate a collective view on the nature." 23 The myriad of confusion resulting from past word choices seemed enough to justify this standard. For Quebec sovereignist and federalists alike, the address to a clear question was not desired. Firstly, the unilateral position allowing the federal government to dismiss its obligation to negotiate sovereignty in cases of ambiguity was not supported

${ }^{23}$ Monahan, Rules, 23. 
by Quebecer's. ${ }^{24}$ Secondly, Claude

Ryan argues that the "collective view"

approach is an example of federal intrusion in provincial matters. He argues of a contradiction within the Act:

The federal government recognizes... "the government in any province of Canada is entitled to consult its population by referendum on any issue and is entitled to formulate the wording of its referendum question." But it contradicts this recognition by a provision in the clarity bill that confers on the federal parliament direct power of intervention...by its own admission, this process lies within the jurisdiction of the Quebec National Assembly. ${ }^{25}$

Superficially, the federal government appeared to have formulated a clear question definition that was equitable. But the contradiction renders its effective value as flawed in regards to the autonomy of the National Assembly. It raises the legal argument of ultra

${ }^{24}$ Ryan, Consequences, 22. 25 Ibid. vires from the targeted province. Ryan directly challenges Monahan's embraced approval of the "collective view" position in a referendum question.

Referendums are a political statement. It seems counterintuitive for the National Assembly to seek approval for a political declaration from the very body it intends to divide itself from. The effective value of the clear question aspect only aids in Quebec's argument of paternalism by the federal government, as it acts as a negatively connotative proof-reader for the National Assembly. This concern by Quebecer's is - unfortunately effectively legitimatized by the Act. Analogous with Trudeau's defense during the constitution partition, it reinforces the view that sovereigntist governments cannot act on the best interests of Quebecers. The blanket assumption that only the federal government can offer fair representation and equity is problematic. It challenges democracy and undermines the elected officials of the National Assembly, rendering official representatives as moot. This 
assumption is dangerous. Thus, elements of the Clarity Act are problematic. This cannot be the desired effect of the federal government if it intends to be equitable. If it does not create legal oppression, as the SCC rejects, it perpetuates a theoretical one.

The problematic parts of the clear question argument pales in comparison to the decisive matter of defining what constitutes a clear majority. A distinctive ineffective element of the Clarity Act resides with its failure to quantify what is a clear majority. This part of the Act can be outright considered ineffective because not only does it not clarify, but it convolutes the issue. Evidence of this ill-defined area of the Act is demonstrated within political literature. Theorists can only speculate what could consitutute as a majority based on polling opinions of the voting majority and other socioenviromental factors. ${ }^{26}$ Speculation amongst the echelon should not dominate if there is a

${ }^{26}$ Monahan, Rules, 26. decisive, definitive, and predictable manner of determining a majority. This is of utmost important if the sole reasoning for a piece of legislation is to be decisive! Its definitional nature is vague, and only addresses what quantitative value is not acceptable, which is $50 \%+1$, yet there is a failure to supplement it. For Monahan who supports the Act, even he states that there is societal uncertainty, whereby questions of transparency and accountability can occur. There can be confusion and disorder if a majority figure is not established and a very close race was to ensue. ${ }^{27}$ This is a serious flaw to the Clarity Act as a whole document because of the importance of the clear majority issue. It acts as one half of the necessary component needed for sovereignty negotiations to take place.

In areas where the federal government did achieve success was in regards to Aboriginals and the issues of border. The Act attempts to be more inclusive as evident in what is considered the multilateral

\footnotetext{
${ }^{27}$ Ibid., 32.
} 
negotiation model, whereby

Aboriginals are included in the

negotiation processes of sovereignty. ${ }^{28}$

For Aboriginals their tries are closer

to the federal government though

they, like the Quebecer's, have also

experienced the patronizing

extensions of the government. As

Peter Russell and Bruce Ryder

highlight, "it must also be recognized

that there are a number of Aboriginal

peoples within the province of Quebec

whose right to self-determination - in

both moral and legal terms - is as

strong, if not stronger, as any that the

Québécois can claim."29 The

inclusiveness of Aboriginals is

important for this group after being

marginalized during the 1980 and

1995 referendums. A concern for the

Quebec government is the

overwhelming support against

sovereignty -showing $96 \%$

opposition. ${ }^{30}$ The inclusion gives the

28 Ibid., 14.

${ }^{29}$ Russell and Ryder, Postreferendum,

327.

30 Aboriginal Peoples and the 1995

Quebec Referendum: A Survey of the Issues, Parliamentary Research Branch (PRB) of the Library of Parliament,

February 1996. federal government greater

negotiating power, as First Nations

are within the jurisdictional

responsibility of the federal

government. The Act is effective in the

sense it includes former marginalized groups.

The extension of Aboriginal's inclusiveness also overlaps with issues of land and boundaries. The second positive aspect of the Clarity Act is its address to the border issues within Quebec, and the possibility of renegotiating land divisions. The federal government's position on this issue reflects the inclusiveness and consideration of Quebec regions who overwhelmingly may decide to vote "no" in a referendum campaign. This legal effect weakens the standing claim by sovereignty leaders who argue that border negotiations would not be subjected. This follows the hardening position of the Plan B initiative. Scholars have noted, "a refusal to negotiate and adjust borders would mean that the Quebec government was not conducting itself in accordance with the mandated 
negotiation framework." ${ }^{1}$ Though two issues stand as the more positive elements of the Act, they are not able to sufficiently overshadow the flaws of the two necessary principles needed to trigger the debates of Aboriginal rights and border issues.

Legitimacy of the Clarity Act- Legality and Recognition

For Quebecers, there is a strong sense of the rule of law. Despite not signing the Canadian Constitution, its people have abided and contributed as supporters of the rights based vision of federalism. The conceptions of democracy and the rule of law are necessary in the evaluations of the extent of legitimacy in the Secession Reference and Clarity Act. To define the application of "legitimacy," Claude Ryan argues that it is supported on a foundation of the rule of law. He states, "legitimacy and legality must go hand in hand in democratic society." He qualifies this by quoting the Secession Reference, "[D]emocracy in any real sense of the word cannot exist without the rule of law. It is the

${ }^{31}$ Monahan, Rules, 20. law that creates the framework within which the "sovereign" will is to be ascertained and implemented. To be accorded legitimacy, democratic institutions must rest, ultimately, on a legal foundation." 32 The examination of legitimacy will emphasize legal legitimacy and also the legitimate value of the Clarity Act as recognized by the Quebec government.

In regards to legal legitimacy of the Clarity Act, to what extent is the Secession Reference democratic and abiding by the rules of law? Firstly, proceeding in a nonconsensual manner to the SCC is problematic. The Act can be deemed as not legitimate because Quebec, did not participate, nor support the Reference. The importance of a consensual piece of legislation contributes to the degree of legitimacy, as argued by Russell and Ryder, "we hold the view that, if there is to be a radical change in Quebec's constitutional status - including its becoming an independent state -such as change should be effected through a process that is consensual and retains

\footnotetext{
${ }^{32}$ Ryan, Consequences, 22.
} 
legal continuity." 33 Forcefully bringing a province into the fold of constitutional matters challenges the notion of equality of power in the federalism model.

Secondly, legally interpreting sovereignty as exclusive to political influences is problematic. Quebec felt that the role of the SCC was strictly legal in nature and not political, as the issues of sovereignty was categorized as. Moving the issue to the legal sphere undermines the initial position of the federal government; hence questioning its authoritative role. The orthodox view of the federal government supports this as they "chose not to intervene in a matter that was 'political' rather than legal" in reference to the 1995 referendum. ${ }^{34}$ The decision to refer the question of secession is a contradiction of the government in times of panic. Quebec can argue that the political nature gives the SCC no authority to be decisive on the matter. Furthermore, this dramatic shift compromises the

${ }^{33}$ Russell and Ryder, Postreferendum, 324. ${ }^{34}$ Young, The Struggle, 68. validly of the Reference, because of the difficulty in separating "law" and "politics" in an issue that is historically and socially convoluted, yet integral to understanding the present issue of sovereignty. It is a political beast that the SCC ambitiously determined as able to "clearly be interpreted as directed to legal issues." 35 It can not be directed in a pure legal sense without trading off vital contextual factors in the issue itself.

The third problematic element of the legitimate value of the Act is the methodology used. The legal philosophy of the SCC in answering the Reference question departs from the application of case law; which judgments are to be based on. This problem is raised by Claude Ryan who argues that:

Its answers pertain to the legal and juridical aspects of those questions, that would mainly discuss unilateral secession, and it intends to leave...the genuinely political aspects of secession...Such a exclusively

${ }^{35}$ Ryan, Consequences, 1-2. 
juridical approach, however has

inherent limitations. By restricting its

analysis to the legal aspects of the

questions put to it, the Supreme Court

necessarily has to interpret reality

based on legal concepts.

The case law regarding

sovereignty is restricted, or as

Monahan argues as riddled with "gaps." ${ }^{6}$ It is based on judgment that is intuitive where standards cannot be measurable and compared. It is a slippery slope of interpreting sensitive constitutional matters. Furthermore, there is a built in legal bias, as the pressure to be equitable is more significant because it deals with the monumental issue of nationhood itself. No judge wants to be the judge that creates precedence in breaking up the country. Hence, the language used can often be vague and even shallow; a dominant criticism of the Clarity Act. This is an immense burden for a panel of nine judges. The legitimate value of a piece of legislation is not strong if the foundation that it is built on is

${ }^{36}$ Monahan, Rules, 9. weak, and the walls of interpretation as compacted by intuitive standards.

The strongest means of proving a legitimate piece of legislation is through its application and decisive power. The response of Bill 99 by the Quebec government is a formal dismissal of the Act by the National Assembly. It neuters the legitimate authority of the Act. For the federal governments, its goal was to assert its position and define its obligations in cases of sovereignty negotiation. In the opinion of the Quebec government, this vision and exertion of power is not viewed as democratic in accordance with the definition of legitimate that we use to measure. The counterlegislation of Bill 99 acts as a statement of the Clarity Act's application as law, one that is not recognized. Though the validity of Bill 99 is challenged by federalist Quebecers, it is more a symbolic message of self-determination. ${ }^{37}$ It is a defiant statement of the right to selfdetermination. It garners historical feelings that are more in line with the

${ }^{37}$ Ibid., 25. 
Quiet Revolution years, in the belief that Quebec and only Quebec are masters of their house.

\section{Conclusion}

The growing fracture of the two founding races culminated in the trending away from the collective ignorance regarding the issue of Quebec self determination. Struck after the 1995 referendum, the Clarity Act has continued to raise new constitutional issues regarding Quebec. In this examination we have challenged the degree the Act has been in terms of the defined standards of effectiveness and legitimacy. We have argued that the Clarity Act has not met the definition of both. It has been demonstrated that the Clarity Act did not sufficiently fulfill the gaps or intended goals of the federal government. Within the legislation there were contradictions regarding the issue of a clear question and furthermore, it convoluted the definition of what constituted a clear majority. The failure to support the two necessary pillars needed for sovereignty negotiation to take place deemed it as ineffective despite making gains in the areas of Aboriginal rights and border claims. The ineffectiveness of the Act is synonymously coupled with raised concerns of its legal authority. Three fundamental problems occurred: Quebec was excluded from the Secession Reference process, the restrictive nature of answering a legal question regarding sovereignty was problematic, and the departure from case law was a slippery slope towards interpretation. Sovereignty is a product of social and political experiences that are not mutually exclusive with the rule of law. Quebec's position against the Clarity Act is emphasized in its counterlegislation with Bill 99. These foundational problems weakened its lawmaking authority, applicability and importantly its legitimate and effective value. 


\section{Works Cited}

Aboriginal Peoples and the 1995 Quebec Referendum: A Survey of the Issues. Parliamentary Research Branch (PRB) of the Library of Parliament. February 1996.

Cairns, Alan C. "Looking into the Abyss." in The referendum papers: essays on secession and national unity., ed. David R. Cameron, Toronto: University of Toronto Press, 1999, 199-243.

Courchene, Thomas. "The changing nature of Quebec-Canada relations: From the 1980 referendum to the summit of the Canadas." IRPP Working Paper Series, 08 (2004): 1-20.

Gagnon, Alain G. "Quebec's Constitutional Odyssey.” in Canadian Politics, ed. James Bickerton and Alain-G. Gagnon (Peterborough: Broadview Press, 1999), 296.

Lajoie, Andree. "The Clarity Act in its Context." in Quebec: State and Society (third edition), ed. Alain- G. Gagnon, Peterborough: Broadway Press, 2004, 151-163.

Monahan, Patrick. "Doing the rules: An assessment of the federal Clarity Act in light of the Quebec Secession Reference." C.D. Howe Institute (2000):1-39.

Reference re Secession of Quebec, [1998] 2 S.C.R. 217.

Rocher Francois and Miriam Smith. "The four dimensions of Canadian federalism." in New trends in Canada federalism (second edition). Peterborough: Broadview Press, 2003, 21-41.

Russell, Peter and Bruce Ryder. "Ratifying a post-referendum Agreement." in The referendum papers: essays on secession and national unity., ed. David R. Cameron, Toronto: University of Toronto Press, 1999, 323-362.

Ryan, Claude. "Doing the Consequences of the Quebec Secession Reference: The Clarity Bill and beyond." C.D. Howe Institute (2000): 1-32.

Young, Robert. The Struggle for Quebec: From Referendum to Referendum?. Montreal \& Kingston: McGill-Queen's University Press, 1999. 